\title{
Antibacterial and resistance-modifying activities of thymoquinone against oral pathogens
}

\author{
Bochra Kouidhi $i^{*}$, Tarek Zmantar ${ }^{1 *}$, Hanene Jrah ${ }^{3}$, Yosra Souiden², Kamel Chaieb ${ }^{1}$, Kacem Mahdouani ${ }^{2}$ and \\ Amina Bakhrouf ${ }^{1}$
}

\begin{abstract}
Background: The presence of resistant bacteria in the oral cavity can be the major cause of dental antibiotic prophylaxis failure. Multidrug efflux has been described for many organisms, including bacteria and fungi as part of their drugs resistance strategy. The discovery of a new efflux pump inhibitor could extend the useful lifetime of some antibiotics.

Methods: In this study, the MICs of thymoquinone (TQ), tetracycline and benzalkonium chloride (BC) were determined in absence and in presence of a sub-MIC doses of thymoquinone (1/2 MIC). In addition the 4,6diamidino-2-phenylindole (DAPI) efflux assay was carried out to determine the effect of TQ on DAPI cells accumulation.
\end{abstract}

Results: TQ induced a selective antimicrobial activity. Its synergic effect resulted in at least a 4-fold potentiation of the tested antibiotics and antiseptic. In addition, TQ inhibited the DAPI efflux activity in a concentration-dependent manner. The rate of DAPI accumulation in clinical isolates was enhanced with TQ $(0$ to $200 \mu \mathrm{g} / \mathrm{ml}$ ). There is also a decrease in loss of DAPI from bacteria in the presence of TQ. The concentration causing $50 \%$ of DAPI efflux inhibition after 15 minutes was approximately $59 \mu \mathrm{g} / \mathrm{ml}$ for Pseudomonas aeroginosa and $100 \mu \mathrm{g} / \mathrm{ml}$ and Staphylococcus aureus respectively.

Conclusions: TQ possesses a selective antibacterial activity against oral bacteria. It is therefore suggested that TQ could be used as a source of natural products with resistance-modifying activity. Further investigation is needed to assess their clinical relevance.

\section{Background}

The human oral cavity is an habitat for about 500 cultivable and non-cultivable bacterial species [1]. They have also been implicated in the aetiology of a number of systemic diseases such as infective endocarditis, respiratory infections and cardiovascular diseases [2-4]. Streptococcus spp. have been implicated as primary causative agents of dental caries, especially, Streptococcus mutans and Streptococcus sobrinus $[5,6]$.

Bacteria are exceptionally adept at acquiring resistance to antibiotics and antiseptic agents [7]. Sweeney et al., [8] reported the resistance of oral bacteria to pencillins, tetracycline and macrolides. The difficulty in treating

\footnotetext{
* Correspondence: bochrak@yahoo.fr; zmantar_t@yahoo.fr

'Laboratory of Analyses, Treatments and Valorisation of Environmental Wastes and Products, Faculty of Pharmacy, Monastir University, Avicenne Street 5000 Monastir, Tunisia

Full list of author information is available at the end of the article
}

multi-resistance bacterial infections is compounded by the fact that many strains also possess efflux pumps (e.g. TetK and MsrA, NorA and QacA) which confer resistance to various antibiotics and antiseptics [9].

Natural compounds have been recently investigated as promising agents for the prevention of dental caries [10]. Nigella sativa L. is an annual herbaceous plant belonging to the Ranunculaceae family growing in countries bordering the Mediterranean Sea [11]. The seeds of Nigella sativa $\mathrm{L}$. have been particularly used in the traditional Arab herbal medicine for the treatment of various diseases [12]. Many biological activities of N. sativa seeds have been reported, including: antibacterial, antifungal, anti-tumor, and hypotensive [13-16].

Thymoquinone was the bioactive constituent of the volatile oil of $N$. sativa [17]. Moreover, it has been reported that TQ have antibacterial potency and its
C Biomed Central

C 2011 Kouidhi et al; licensee BioMed Central Ltd. This is an Open Access article distributed under the terms of the Creative Commons Attribution License (http://creativecommons.org/licenses/by/2.0), which permits unrestricted use, distribution, and reproduction in any medium, provided the original work is properly cited. 
activity can enhance antibiotic actions especially against S. aureus [18].

The rapid spread of bacteria expressing multidrug resistance has necessitated the discovery of new antibacterial and resistance-modifying agents. Efflux pumps have been known to extrude structurally diverse compounds, including antibiotics and antiseptics used in a clinical setting [9]. The combination of a broad-spectrum multidrug-resistant (MDR) pump inhibitor with antibiotics could reduce the morbidity and mortality that might result from a delay in the institution of effective therapy for serious S. aureus infections [19]. Antimicrobial and efflux pumps inhibiting activities of natural compounds have been reported for several natural based products such as rosemary, kaempferol, propolis and aqueous khat extracts [20-23].

The aim of this study was to evaluate the in vitro inhibitory and resistance-modifying properties of TQ alone or in combination with tetracycline and $\mathrm{BC}$ against a panel of pathogenic bacteria.

\section{Methods}

\section{Microorganisms}

The cariogenic strains $(n=16)$ used in this study were isolated from Tunisian children suffering for dental caries (Monastir, Center of Tunisia). The strains were isolated on blood agar plates supplemented with 5\% sheep blood and identified by conventional methods.

11 reference strains were further included in this study. All the used bacteria were listed in Table 1.

\section{Chemicals used}

All the media used in this study were purchased from Biorad (France), thymoquinone from Sigma-Aldrich (Switzerland) and benzalkonium from Acros organics (USA).

\section{Minimum inhibitory concentration (MIC) value determination assay}

The broth microdilution method was used to determine the minimum inhibitory concentration (MIC) of TQ against the tested strains as recommended by the Clinical and Laboratory Standards Institute (CLSI) [24]. Cells $\left(10^{6} / \mathrm{ml}\right)$ were inoculated into Mueller-Hinton broth and dispensed at $0.2 \mathrm{ml} /$ well in 96-well microtiter plates. The TQ was properly prepared and transferred to each microplate well in order to obtain a twofold serial dilution ranging from 0.5 to $256 \mu \mathrm{g} / \mathrm{ml}$. The inocula $(10 \mu \mathrm{L})$ containing $510^{5} \mathrm{CFU}$ of each microorganism were added to each well. A number of wells was reserved in each plate for sterility control (no inoculate added) and inocula viability (no TQ added). All MICs tests were repeated three folds in separate times. Plates were incubated at $37^{\circ} \mathrm{C}$ for $24 \mathrm{~h}$ and bacterial growth was evaluated by the presence of turbidity and a pellet on the well bottom. MIC value was defined as the lowest concentration of the antimicrobial compound that had no macroscopically visible growth.

\section{Resistance modifying assay}

To test the resistance-modifying activity of $\mathrm{TQ}$, the tetracycline and benzalkonium chloride $(\mathrm{BC}) \mathrm{MICs}$ ranging from 0.5 to $256 \mu \mathrm{g} / \mathrm{ml}$ were determined against the selected strains with or without TQ at $1 / 2$ of its MIC value using the microtiter plates assay [23]. All experiments were carried out three times.

\section{Minimum bactericidal concentration (MBC) value determination assay}

To determine the MBCs values, $10 \mu \mathrm{l}$ from each well of broth with no visible growth were removed and inoculated on Muller Hinton agar plates. After 18-24 h of incubation at $37^{\circ} \mathrm{C}$, the number of surviving bacteria was noted. $\mathrm{MBC}$ value was defined as the lowest concentration of compounds (TQ, tetracycline and $\mathrm{BC}$ ) needed to kill $99 \%$ of bacteria. Each experiment was repeated at least twice [25].

\section{Efflux assay}

The 4,6-diamidino-2-phenylindole (DAPI) efflux assay was carried out as described previously [26]. Briefly, cells were grown in $20 \mathrm{ml}$ of Luria-Bertani (LB) broth until the optical density at $650 \mathrm{~nm}$ reached 0.7 units. The cells were washed with modified Tanaka buffer and were resuspended in the same buffer containing $5 \mu \mathrm{M}$ of DAPI and $1 \mathrm{mM}$ 2,4-dinitrophenol (DNP), and incubated at $37^{\circ} \mathrm{C}$ for $10 \mathrm{~h}[27,28]$. DNP, which is a well-known conductor of protons across the cytoplasmic membrane, was used to de-energize the cells [29].

Similar steps were repeated to obtain an optical density of 0.4 units at $650 \mathrm{~nm}$. The fluorescence of DAPI was measured at excitation and emission wavelengths of 355 and $457 \mathrm{~nm}$ respectively, with a Spectrofluorophotometer, model RF-5301PC (Shimadzu). The fluorescence intensity of DAPI is higher when DAPI binds to DNA molecules. Thus, the efflux of DAPI from the cell can be monitored by the detection of a decrease in the level of fluorescence over time. After incubation of the cell suspension at $37^{\circ} \mathrm{C}$ for $5 \mathrm{~min}$, glucose $(20 \mathrm{mM})$ was added as an energy source to monitor the efflux of DAPI.

To evaluate the effects of TQ on the efflux of DAPI, cell suspensions were prepared in the same way as described above. Cell suspensions were pre-incubated for $5 \mathrm{~min}$ at $37^{\circ} \mathrm{C}$ with different concentrations of TQ (0 to $200 \mu \mathrm{g} / \mathrm{ml}$ ) prior to the addition of glucose. 
Table 1 Minimum inhibitory and minimum bactericidal concentrations in $\mu \mathrm{g} / \mathrm{ml}$ of thymoquinone and tetracycline and their combination

$\begin{array}{lllcc}\text { MIC TQ } & \text { MBC TQ } & \text { MIC TET } & \text { MBC TET } & \text { a MIC TET } \\ +1 / 2 \text { MIC TQ } & \begin{array}{c}\text { MBC TET } \\ +1 / 2 \text { MIC TQ }\end{array}\end{array}$

References strains

Bacillus cereus ATCC 14579

Escherichia coli ATCC 35218

Enterococcus faecalis ATCC 29212

Salmonella enterica serovar Typhimurium ATCC 1408

Staphylococcus aureus ATCC 25923

Staphylococcus epidermidis CIP 106510

Listeria monocytogenes ATCC 19115

Micrococcus luteus NCIMB 8166

Pseudomonas aeruginosa ATCC 27853

Vibrio alginolyticus ATCC 33787

Vibrio paraheamolyticus ATCC 17802

Oral strains

E. faecalis B281

Gemella haemolysans B234

Staphylococcus aureus B73

Staphylococcus aureus B285

Staphylococcus aureus B291

Staphylococcus aureus B289

Staphylococcus aureus B456

Staphylococcus aureus B244

Staphylococcus aureus B364

Staphylococcus aureus B398

Streptococcus anginosus B486

Streptococcus constellatus B629

Streptococcus mitis B627

Streptococcus mutans B509

Streptococcus oralis B634

Streptococcus salivarius B468

$\begin{array}{ccc}8 & 8 & \\ 512 & 512 & \\ 32 & 128 & 256 \\ 256 & 512 & 128 \\ 8 & 16 & \\ 8 & 8 & \\ 32 & 128 & \\ 8 & 64 & 32 \\ >512 & >512 & 64 \\ 512 & 512 & 256 \\ 32 & 64 & \\ & & \end{array}$

$\begin{array}{cc}2 \\ 4 \\ 256 & 512 \\ 128 & 256 \\ 4 & \\ 8 & 8 \\ 1 & \\ 32 & \\ 64 & 128 \\ 256 & 512 \\ 4 & 32\end{array}$

\begin{tabular}{|c|c|c|}
\hline 8 & $0.5(4)$ & $4(2)$ \\
\hline 16 & $2(2)$ & $64(4)$ \\
\hline 512 & $128(2)$ & $64(8)$ \\
\hline 256 & $32(4)$ & $128(2)$ \\
\hline 8 & $0.5(8)$ & $4(2)$ \\
\hline 16 & $4(2)$ & $64(4)$ \\
\hline 4 & $1(\mathrm{NC})$ & $4(\mathrm{NC})$ \\
\hline 64 & $8(4)$ & $16(4)$ \\
\hline 128 & $32(2)$ & $256(2)$ \\
\hline 512 & $128(2)$ & $256(2)$ \\
\hline 32 & $0.5(8)$ & $8(4)$ \\
\hline 256 & 64 (NC) & $128(2)$ \\
\hline 256 & $256(2)$ & 256 (NC) \\
\hline 128 & $16(4)$ & $16(8)$ \\
\hline 4 & $4(\mathrm{NC})$ & $8(2)$ \\
\hline 128 & $32(4)$ & $64(2)$ \\
\hline 4 & $<0.5(>8)$ & $2(2)$ \\
\hline 128 & $4(8)$ & $16(8)$ \\
\hline 32 & $4(8)$ & $8(4)$ \\
\hline 8 & $8(2)$ & $8(\mathrm{NC})$ \\
\hline 16 & $4(4)$ & $4(4)$ \\
\hline 256 & $64(2)$ & $128(2)$ \\
\hline 4 & $<0.5(\mathrm{NC})$ & $4(\mathrm{NC})$ \\
\hline 256 & $32(4)$ & $128(2)$ \\
\hline 8 & $<0.5(\mathrm{NC})$ & $4(2)$ \\
\hline 128 & $32(4)$ & $64(2)$ \\
\hline 16 & $2(2)$ & $8(2)$ \\
\hline
\end{tabular}

${ }^{a}$ Fold reductions are given in parentheses; NC, no change; TQ, thymoquinone; TET, Tetracycline

\section{Results}

\section{Antibacterial activity of thymoquinone}

The antibacterial activities of TQ against the tested strains were shown in Table 1. TQ demonstrated a selective antimicrobial property. Seven out of 16 oral strains, particularly Staphylococcus aureus (B285, B289, B456, B244 and B398), Streptococcus mutans (B509), Streptococcus salivarius (B468), and four out of 11 laboratory reference strains, which consist of Staphylococcus epidermidis CIP 106510, Staphylococcus aureus ATCC 25923 Micrococcus luteus NCIMB 8166 and Bacillus cereus ATCC 14579 were sensitive to TQ with MIC and MBC values ranging from 8 to $64 \mu \mathrm{g} / \mathrm{ml}$. Six clinical and four reference strains were resistant to TQ with MIC values ranged between 128 to $512 \mu \mathrm{g} / \mathrm{ml}$ (Table 1 and 2). Furthermore, the most resistant strain was Pseudomonas aeroginosa with a MIC of value $>512 \mu \mathrm{g} / \mathrm{ml}$.

\section{Resistance modifying properties of thymoquinone}

Data presented in Table 1 showed that the supplementation of TQ (at 1/2 MIC) induces the highest decrease of eight-fold MIC value of tetracycline against $S$. aureus ATCC 25923, S. aureus B289 and Vibrio paraheamolyticus ATCC 17802. Additionally, a four-fold reduction of tetracycline MIC value was observed against five clinical and three reference strains. A twofold potentiation of the tetracycline activity against five reference and four clinical isolates was also noted (Table 1).

Similarly, an eight-fold potentiation of BC with the addition of TQ (at 1/2 MIC) was recorded against the same three reference strains with additional four S. aureus isolated from the oral cavity. Furthermore, a fourfold BC MIC reduction was noted against $B$. cereus ATCC 14579 and S. aureus B285 (Table 2). 
Table 2 Minimum inhibitory and minimum bactericidal concentrations in $\mu \mathrm{g} / \mathrm{ml}$ of benzalkonium with and without thymoquinone supplementation

\begin{tabular}{|c|c|c|c|c|}
\hline Strains & $\begin{array}{c}\mathrm{MIC} \\
\mathrm{BC}\end{array}$ & MBC BC & $\begin{array}{l}\mathrm{a} \mathrm{MIC} \text { BC }+ \\
1 / 2 \mathrm{MIC} \text { TQ }\end{array}$ & ${ }^{\mathrm{a}} \mathrm{MBC} \mathrm{BC}+1 / 2 \mathrm{MIC}$ TQ \\
\hline \multicolumn{5}{|l|}{ References strains } \\
\hline B. cereus ATCC 14579 & 16 & 32 & $4(4)$ & $8(4)$ \\
\hline E. coli ATCC 35218 & 16 & 32 & $16(\mathrm{NC})$ & $16(2)$ \\
\hline E. faecalis ATCC 29212 & 8 & 16 & $4(2)$ & $4(4)$ \\
\hline L. monocytogenes ATCC 19115 & 1 & 4 & $1(\mathrm{NC})$ & $2(2)$ \\
\hline M. luteus NCIMB 8166 & 16 & 16 & $2(8)$ & $4(4)$ \\
\hline S. enterica serovar Typhimurium ATCC 1408 & 32 & 64 & $32(\mathrm{NC})$ & $64(\mathrm{NC})$ \\
\hline S. aureus ATCC 25923 & 16 & 32 & $2(8)$ & $4(8)$ \\
\hline S. epidermidis CIP 106510 & 4 & 8 & $2(2)$ & $4(2)$ \\
\hline P. aeruginosa ATCC 27853 & 128 & 256 & $128(\mathrm{NC})$ & $256(\mathrm{NC})$ \\
\hline V. alginolyticus ATCC 33787 & 32 & 64 & $16(2)$ & $32(2)$ \\
\hline V. paraheamolyticus ATCC 17802 & 32 & 128 & $4(8)$ & $16(8)$ \\
\hline \multicolumn{5}{|l|}{ Oral strains } \\
\hline E. faecalis B281 & 256 & $>256$ & $256(N C)$ & $>256$ (NC) \\
\hline Gemella haemolysans B234 & 8 & 32 & $4(2)$ & $8(4)$ \\
\hline S. aureus B73 & 16 & 32 & $2(8)$ & $8(4)$ \\
\hline S. aureus B285 & 8 & 16 & $2(4)$ & $4(4)$ \\
\hline S. aureus B291 & 16 & 16 & $2(2)$ & $4(4)$ \\
\hline S. aureus B289 & 8 & 16 & $<1(>8)$ & $2(8)$ \\
\hline S. aureus B456 & 4 & 8 & $<1(>8)$ & $2(4)$ \\
\hline S. aureus B244 & 2 & 8 & $<1(>8)$ & $2(4)$ \\
\hline S. aureus B364 & 64 & 128 & $8(>8)$ & $32(4)$ \\
\hline S. aureus B398 & 4 & 8 & $<1(>8)$ & $2(4)$ \\
\hline S. anginosus B486 & 8 & 16 & $4(2)$ & $8(2)$ \\
\hline S. constellatus B629 & 4 & 16 & $2(2)$ & $4(4)$ \\
\hline S. mitis B627 & 4 & 8 & $4(\mathrm{NC})$ & $16(2)$ \\
\hline S. mutans B509 & 4 & 8 & $2(2)$ & $4(2)$ \\
\hline S. oralis B634 & $>256$ & $>256$ & $>256$ (NC) & $>256$ (NC) \\
\hline S. salivarius B468 & 8 & 16 & $4(2)$ & $8(2)$ \\
\hline
\end{tabular}

${ }^{\mathrm{a}}$ Fold reductions are given in parentheses; $\mathrm{NC}$, no change; $\mathrm{TQ}$, Thymoquinone; $\mathrm{BC}$, benzalkonium chloride

\section{Efflux-mediated properties of thymoquinone}

The efficiency of efflux pumps for which DAPI is a substrate has been assessed fluorometrically. In this study, we investigated the effect of TQ on the DAPI efflux activity. The fluorescence of DAPI increases when it binds to DNA. Glucose was added as an energy source to the assay mixture, which monitor the DAPI efflux.

In the absence of thymoquinone, the addition of glucose after 5 min of experience induced a significant decrease of fluorescence represented by an $\mathrm{x}$ symbol in Figure 1(A, B, C, D) and 1E. However, TQ supplementation inhibit the DAPI efflux

As shown in Figure 2, the intracellular accumulation of DAPI was influenced by TQ in a concentrationdependent manner. Low doses of TQ reduced the DAPI efflux whereas higher doses showed a total inhibition of efflux and even a DAPI accumulation reflected in an increase of fluorescence. As the concentration of TQ increased, the fluorescence was increased indicating the concentration-dependant inhibition of DAPI efflux through active pumps.

The concentration causing 50\% of efflux inhibition after 15 minutes was approximately $59 \mu \mathrm{g} / \mathrm{ml}, 100 \mu \mathrm{g} / \mathrm{ml}$, $169 \mu \mathrm{g} / \mathrm{ml}$ and $177 \mu \mathrm{g} / \mathrm{ml} 177 \mu \mathrm{g} / \mathrm{ml}$ against $P$. aeroginosa, $S$. aureus, $B$. cereus and $V$. parahaemolyticus, respectively (Figure 2).

A similar efflux inhibition was observed for Enterococcus faecalis. However, the maximum of inhibition observed was lower than $30 \%$. These data indicate that at low concentrations, TQ is very effective as an inhibitor of DAPI efflux in the tested bacteria (Figure 2).

\section{Discussion}

One of the most important antibiotic resistance mechanisms is the expression of efflux pumps. The search of a new efflux pump inhibitors (EPIs) is necessary to combat the emergence of MDR strains [30]. 

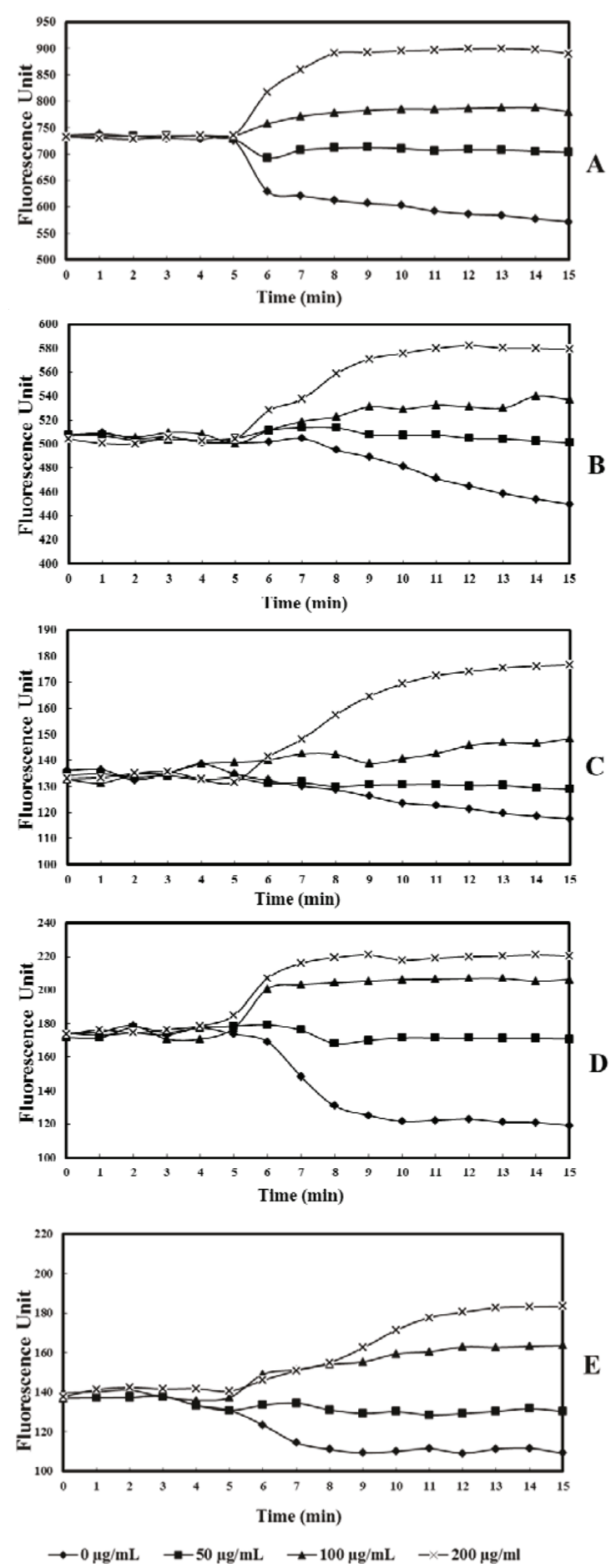

Figure 1 The levels of accumulation of 4,6-diamidino-2phenylindole in pathogenic bacteria alone or in the presence of various concentration of thymoquinone $(0,50,100$ and $200 \mu \mathrm{g} / \mathrm{mL}$ ): A, Bacillus cereus ATCC 14579; B, Enterococcus faecalis ATCC 29212; C, Vibrio parahemolyticus ATCC 17802; D, Pseudomonas aeruginosa ATCC 27853; E, Staphylococcus aureus ATCC 25923.
Data presented in Table 1 revealed a selective antibacterial property of TQ. Seven reference strains and 10 oral isolates were sensitive to TQ with MIC values ranged from 8 to $64 \mu \mathrm{g} / \mathrm{ml}$ while the remaining four Gramnegative reference strains and six oral bacteria were resistant against TQ with MIC values ranging from 128 to $512 \mu \mathrm{g} / \mathrm{ml}$. These results support a previous study which reported an effective and inactive potency of TQ against Gram-positive and Gram-negative bacteria, respectively [18].

Efflux is an important mechanism of resistance in many clinically relevant pathogens, notably, Streptococcus pneumoniae and Pseudomonas aeruginosa [9,31]. The efflux pumps (EPs) are proteins of bacterial membranes which extrude antibiotics and other antimicrobial agents from the cell [32]. These EPs can transport drugs through the bacterial envelope and limit the intracellular accumulation of toxic compounds, such as antibiotics, antimicrobial peptides, metals and detergents [32]. It has been reported that plants provide a rich source of efflux pumps inhibitors (EPIs) [19,30]. Therefore, there is an urgent need for novel drugs with new modes of action, such as EPIs, to prevent the rise of MDR bacteria [20]. EPI activities of natural compounds have been reported elsewhere $[20,21,23]$.

Data presented in Table 1 and 2 showed the potential of TQ to reduce at least a 4-fold the tetracycline and BC MICs value. Similar effect of TQ with other antibiotics has been previously reported [18].

In the case of $\mathrm{BC}$ an 8-fold reduction in MICs values were observed particularly for Staphylococcus aureus and Vibrio paraheamolyticus (Table 2).

The modulating activity of TQ was referred as "Efflux Pump Inhibitors". This expression was adopted for compounds isolated from Lycopus europaeus and Rosmarinus officinalis which modulate resistance of $S$. aureus to tetracycline and erythromycin $[19,20]$. To the best of our knowledge, this is the first report on resistance modifying activity of TQ against resistant oral bacteria.

In a DAPI accumulation assay, we compared the levels of DAPI accumulation in five pathogenic bacteria treated by TQ ( 0 to $200 \mu \mathrm{g} / \mathrm{ml}$ ) during 15 minutes (Figure $1 \mathrm{~A}, \mathrm{~B}, \mathrm{C}, \mathrm{D}$ and $1 \mathrm{E})$. Our data revealed that the addition of TQ induced the increased of DAPI accumulation in the treated strains. The inhibition of DAPI efflux via a number of pumps transporters has been already reported for E. faecalis [26].

We noted also that accumulation of DAPI was further increased following TQ supplementation. As found previously, the MICs of the antibiotics and $\mathrm{BC}$ were also much lower following TQ supplementation. A relative difference in increased accumulation of DAPI in the presence of various TQ concentrations was noted (Figure 2). 


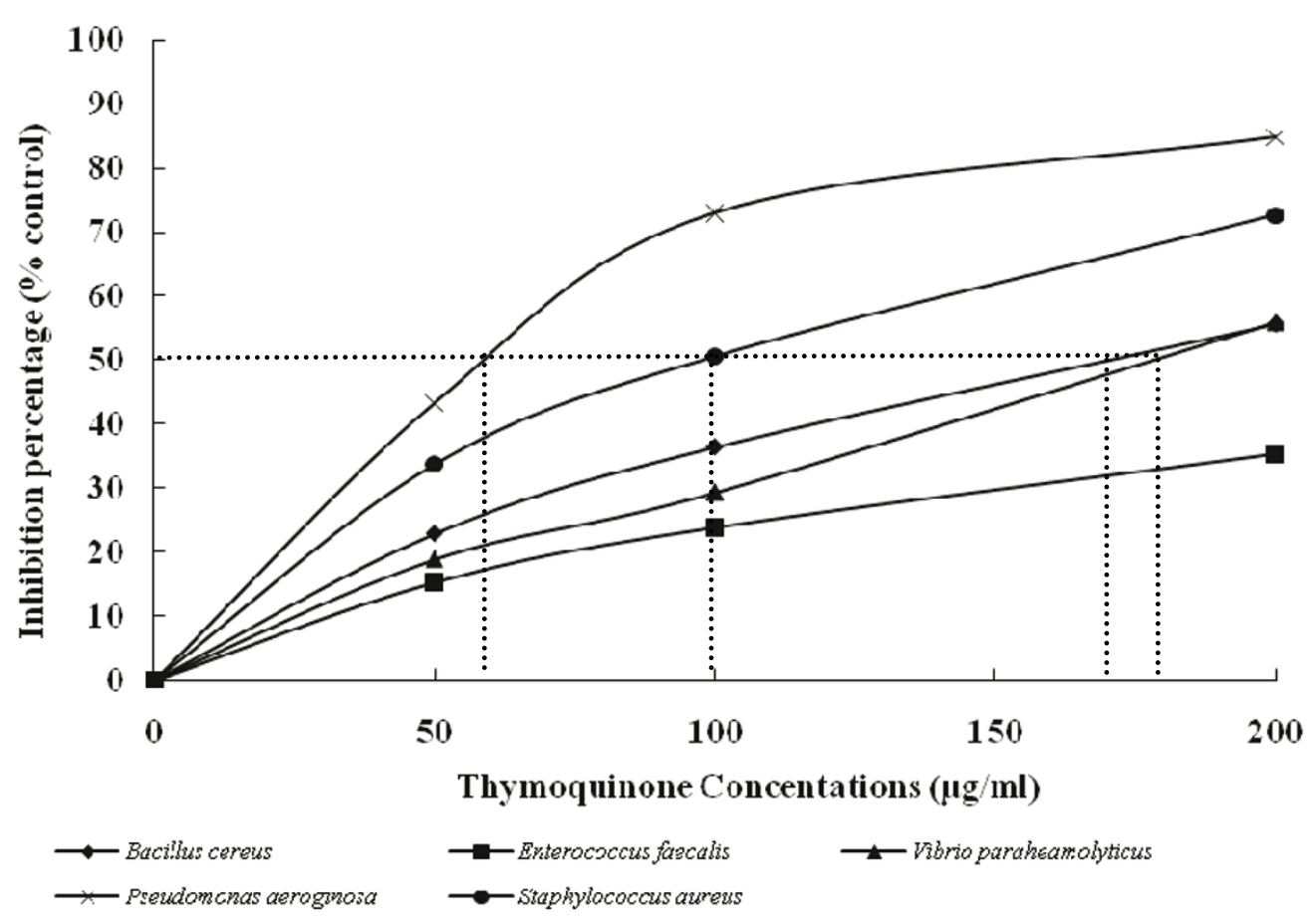

Figure 2 Inhibition of DAPI efflux activity by thymoquinone by different bacteria. Various concentrations of thymoquinone were added, and the mixture was preincubated with the cells for $5 \mathrm{~min}$. Glucose (final concentration, $20 \mathrm{mM}$ ) was added to initiate the assay. The relative initial velocity of DAPI efflux was measured. The initial velocity observed in the absence of Thymoquinone was set at $100 \%$. Dotted lines indicate $I C_{50}$.

These two observations presume the modulating activity of TQ through pumps efflux inhibition leading to antibiotic accumulation in the cells enhancing their effects at lower doses. Furthermore DAPI is known to be substrates for many efflux pumps and no system other than multi-drugs efflux pumps are known to cause resistance to these agents [33-35]. So the inhibition of DAPI efflux supports the hypothesis of antibiotics modulating activity of thymoquinone through pump efflux inhibition.

Modulators of drug resistance would clearly have the benefit for the treatment of multidrug resistant strains for which the majority of therapeutic antibiotics have no further clinical use. Inhibitors of drug efflux mechanisms could, in combination, greatly extend the useful lifetime of older conventional antibiotics such as the tetracycline.

\section{Conclusion}

We have demonstrated that TQ have antibacterial and resistance modifying activity. Thus, the results shown in the present report are encouraging although clinical controlled studies are needed to define the efficacy of TQ. These studies could determine the potential medical use of TQ in combination with selected antimicrobial drugs against bacterial infection.
Since bacteria may be resistant to several antimicrobial drugs, the synergism reported here is of relevance and TQ may constitute an alternative for treating infections related to these pathogens.

\section{Author details}

${ }^{1}$ Laboratory of Analyses, Treatments and Valorisation of Environmental Wastes and Products, Faculty of Pharmacy, Monastir University, Avicenne Street 5000 Monastir, Tunisia. ${ }^{2}$ Laboratory of Molecular Biology, Kairouan Hospital, Tunisia. ${ }^{3}$ Research Unit of Biology and Genetics of Hematological and Auto-immune Diseases, Faculty of Pharmacy, Monastir University, Avicenne Street 5000 Monastir, Tunisia.

\section{Authors' contributions}

BK is the primary author of the manuscript, planed the work, assisted in minimum inhibition concentration determination of $T Q$, tetracycline and $B C$ together and conceived the DAPI efflux assay. TZ contributed in minimum inhibition concentration determination and helped in the writing of the manuscript. HJ participated in data acquisition and contributed in writing of the manuscript. YS helped in DAPI efflux determination, and participated in the writing of the manuscript. KM participated in data acquisition and helped to finalize the manuscript. AB provided funding, supervised the study, and helped to finalize the manuscript.

All the authors read and approved the final version of the manuscript.

\section{Financial competing interests}

Higher education and scientific research in Tunisia through the laboratory of analyses, treatments and valorisation of environmental wastes and products, faculty of pharmacy, Monastir University, street Avicenne 5000 Monastir (Tunisia). 
Received: 4 April 2011 Accepted: 27 June 2011 Published: 27 June 2011

\section{References}

1. Paster BJ, Boches SK, Galvin JL, Ericson RE, Lau CN, Levanos VA, Sahasrabudhe A, Dewhirst FE: Bacterial diversity in human subgingival plaque. J Bacteriol 2001, 183:3770-3783.

2. Barrau K, Boulamery A, Imbert G, Casalta JP, Habib G, Messana T, Bonnet JL, Rubinstein $E$, Raoult $D$ : Causative organisms of infective endocarditis according to host status. Clin Microbiol Infect 2004, 10:302-308.

3. Mojon $\mathrm{P}$, Bourbeau J: Respiratory infection: how important is oral health? Curr Opin Pulm Med 2003, 9:166-170.

4. Okuda K, Kato T, Ishihara K: Involvement of periodontopathic biofilm in vascular diseases. Oral Dis 2004, 10:5-12.

5. Hamada S, Koga T, Ooshima T: Virulence factors of Streptococcus mutans and dental caries prevention. J Dent Res 1984, 63:407-411.

6. Loesche WJ: Role of Streptococcus mutans in human dental decay. Microbiol Rev 1986, 50:353-380.

7. Kouidhi B, Zmantar T, Hentati H, Najjari F, Mahdouni K, Bakhrouf A: Molecular investigation of macrolide and Tetracycline resistances in oral bacteria isolated from Tunisian children. Arch Oral Biol 2011, 56:127-135.

8. Sweeney LC, Dave J, Chambers PA, Heritage J: Antibiotic resistance in general dental practice-a cause for concern? J Antimicrob Chemother 2004, 53:567-576.

9. Marshall NJ, Piddock LJ: Antibacterial efflux systems. Microbiologia 1997, 13:285-300.

10. Pai MR, Acharya LD, Udupa N: Evaluation of antiplaque activity of Azadirachta indica leaf extract gel-a 6-week clinical study. J Ethnopharmacol 2004, 90:99-103.

11. Phillips JD: Medicinal plants. Biologist 1992, 39:187-191.

12. Abu-Irmaileh BE, Afifi FU: Herbal medicine in Jordan with special emphasis on commonly used herbs. J Ethnopharmacol 2003, 89:193-197.

13. Ferdous AJ, Islam SN, Ahsan M, Hasan CM, Ahmed ZU: In vitro antibacterial activity of the volatile oil of Nigella sativa seeds against multiple drug-resistant isolates of Shigella spp. and isolates of Vibrio cholerae and Escherichia coli. Phytotherapy Research 2006, 6:137-140.

14. Hanafy MS, Hatem ME: Studies on the antimicrobial activity of Nigella sativa seed (black cumin). J Ethnopharmacol 1991, 34:275-278.

15. Worthen DR, Ghosheh OA, Crooks PA: The in vitro anti-tumor activity of some crude and purified components of blackseed, Nigella sativa L. Anticancer Res 1998, 18:1527-1532.

16. Zaoui A, Cherrah Y, Lacaille-Dubois MA, Settaf A, Amarouch H, Hassar M: Diuretic and hypotensive effects of Nigella sativa in the spontaneously hypertensive rat. Therapie 2000, 55:379-382

17. El-Dakhakhany M: Studies on the chemical constitution of Egyptian N. sativa L. seeds. Planta Medica 1963, 11:465-470.

18. Halawani E: Antibacterial Acativity of Thymoquinone and Thymohydroquinone of Nigella sativa $\mathrm{L}$. and Their Interaction with Some Antibiotics. Advances in Biological Research 2009, 3:148-152.

19. Gibbons S, Oluwatuyi M, Kaatz GW: A novel inhibitor of multidrug efflux pumps in Staphylococcus aureus. J Antimicrob Chemother 2003, 51:13-17.

20. Oluwatuyi M, Kaatz GW, Gibbons S: Antibacterial and resistance modifying activity of Rosmarinus officinalis. Phytochemistry 2004, 65:3249-3254.

21. Falcao-Silva VS, Silva DA, Souza Mde F, Siqueira-Junior JP: Modulation of drug resistance in Staphylococcus aureus by a kaempferol glycoside from Herissantia tiubae (Malvaceae). Phytother Res 2009, 23:1367-1370.

22. Fernandes Junior A, Balestrin EC, Betoni JE, Orsi Rde O, da Cunha Mde L, Montelli AC: Propolis: anti-Staphylococcus aureus activity and synergism with antimicrobial drugs. Mem Inst Oswaldo Cruz 2005, 100:563-566.

23. Al-hebshi N, Al-haroni M, Skaug N: In vitro antimicrobial and resistancemodifying activities of aqueous crude khat extracts against oral microorganisms. Arch Oral Biol 2006, 51:183-188.

24. CLSI: Methods for Dilution Antimicrobial Susceptibility Tests for Bacteria That Grow Aerobically. Approved Standard - Seventh Edition CLSI Document M7-A7 2006

25. Magina MD, Dalmarco EM, Wisniewski A jr, Simionatto EL, Dalmarco JB, Pizzolatti MG, Brighente IM: Chemical composition and antibacterial activity of essential oils of Eugenia species. J Nat Med 2009, 63:345-350.

26. Lee EW, Chen J, Huda MN, Kuroda T, Mizushima T, Tsuchiya T: Functional cloning and expression of emeA, and characterization of EmeA, a multidrug efflux pump from Enterococcus faecalis. Biol Pharm Bull 2003, 26:266-270.
27. Morita Y, Komori Y, Mima T, Kuroda T, Mizushima T, Tsuchiya T: Construction of a series of mutants lacking all of the four major mex operons for multidrug efflux pumps or possessing each one of the operons from Pseudomonas aeruginosa PAO1: MexCD-OprJ is an inducible pump. FEMS Microbiol Lett 2001, 202:139-143.

28. Tanaka S, Lerner SA, Lin EC: Replacement of a phosphoenolpyruvatedependent phosphotransferase by a nicotinamide adenine dinucleotidelinked dehydrogenase for the utilization of mannitol. J Bacteriol 1967, 93:642-648.

29. Berger EA: Different mechanisms of energy coupling for the active transport of proline and glutamine in Escherichia coli. Proc Natl Acad SCi USA 1973, 70:1514-1518

30. Stavri M, Piddock $L$, Gibbons S: Bacterial efflux pump inhibitors from natural sources. J Antimicrob Chemother 2007, 59:1247-1260.

31. Markham PN: Inhibition of the emergence of ciprofloxacin resistance in Streptococcus pneumoniae by the multidrug efflux inhibitor reserpine. Antimicrob Agents Chemother 1999, 43:988-989.

32. Piddock $L$ : Clinically relevant chromosomally encoded multidrug resistance efflux pumps in bacteria. Clin Microbiol Rev 2006, 19:382-402

33. Chen J, Morita Y, Huda MN, Kuroda T, Mizushima T, Tsuchiya T: VmrA, a member of a novel class of $\mathrm{Na}(+)$-coupled multidrug efflux pumps from Vibrio parahaemolyticus. J Bacteriol 2002, 184:572-6.

34. Littlejohn TG, Paulsen IT, Gillespie MT, Tennent JM, Midgley M, Jones IG, Purewal AS, Skurray RA: Substrate specificity and energetics of antiseptic and disinfectant resistance in Staphylococcus aureus. FEMS Microbiol Lett 1992, 74:259-265

35. Ogawa W, Li DW, Yu P, Begum A, Mizushima T, Kuroda T, Tsuchiya T: Multidrug Resistance in Klebsiella pneumoniae MGH78578 and Cloning of Genes Responsible for the Resistance. Biol Pharm Bull 2005, 28:1505-1508

doi:10.1186/1476-0711-10-29

Cite this article as: Kouidhi et al:: Antibacterial and resistance-modifying activities of thymoquinone against oral pathogens. Annals of Clinical Microbiology and Antimicrobials 2011 10:29.

\section{Submit your next manuscript to BioMed Central and take full advantage of:}

- Convenient online submission

- Thorough peer review

- No space constraints or color figure charges

- Immediate publication on acceptance

- Inclusion in PubMed, CAS, Scopus and Google Scholar

- Research which is freely available for redistribution

Submit your manuscript at www.biomedcentral.com/submit
C Biomed Central 